\title{
Responses of the Ecological Characteristics and Antioxidant Enzyme Activities in Rotaria Rotatoria to UV-B Radiation
}

\section{Ling-yun Zhu}

Anhui Normal University

\section{Rong Huang}

Anhui Normal

\section{Ye Chen}

Anhui Normal University

\section{Li-bin Zhou}

Peking University

\section{Yi-long Xi}

Anhui Normal University

\section{Xian-ling Xiang ( $\nabla$ xlxiang@ahnu.edu.cn )}

School of Ecology and Environment, Anhui Normal University, Wuhu 241000, Anhui, P.R. China https://orcid.org/0000-0002-1378-5877

\section{Research article}

Keywords: UV-B radiation, Life history, Population growth, Antioxidant enzyme, Rotifer, Rotaria rotatoria

Posted Date: November 18th, 2020

DOl: https://doi.org/10.21203/rs.3.rs-106972/v1

License: (c) (i) This work is licensed under a Creative Commons Attribution 4.0 International License. Read Full License

Version of Record: A version of this preprint was published at Hydrobiologia on July 27th, 2021. See the published version at https://doi.org/10.1007/s10750-021-04671-1. 


\section{Abstract}

Background: UVB radiation is an increasing threat to aquatic organisms, and also a potential driving force for zooplankton population dynamics. The bdelloid rotifer, for its parthenogenesis and high resistance to stress, can be used as an excellent model in ecology and evolutionary biology. Given the strong tolerance of bdelloid rotifer to stressors, we hypothesized that it could hold the ability to tolerate significant UV radiation, and this capacity may be associated with the trade-off strategies among life historic components. With this study, to estimate the ecological effects and responses of antioxidant system against UV radiation, the acute lethal, life history strategies, population growth, and antioxidant enzyme activities were assessed in the bdelloid Rotaria rotatoria after exposure to UV-B radiation.

Results: The persistence of tolerance (evaluating by $\mathrm{LT}_{50}$ ) in rotifer to stress was playing a more vital role than the radiation dose $\left(\mathrm{LD}_{50}\right)$ in survival, with a significant negative correlation between the radiation intensity and $\mathrm{LT}_{50}$. The larger the culture volume, the weaker the lethal effect. Rotifers prolonged their first reproductive time (JP), and shortened their reproductive period (RP) and longevity with the increasing of radiation dose, and the fecundity was significant inhibited by UV-B radiation. These responses can be taken as energy trade-off to retard their mortality. The population density of rotifers increased at the lowest dose of radiation, and then descended with the increasing of UVR dose, and this pattern was also corroborated by detecting the content of SOD and CAT, which suggested that hormesis also applies to $R$. rotatoria under UV-B radiation stress. The enzyme SOD has higher level of content and more sensitive to low UVR than CAT.

Conclusions: The lethal effects of UV-B radiation to organisms depends not only on the conditions they exposed to, like as intensity and time of exposure, but also combination of factors namely, the type and effectiveness of the strategy they employ to cope with the changed environment. The species specificity, ages and physiological status also could be the regulating factors under the stresses, also in this case there was the strategy of energy trade-off between reproduction and survival in rotifers.

\section{Background}

Life history trait, like all other phenotypic attributes, represents a suite of plastic components in a specific environment, and can be seen as compromises to various investments in growth, reproduction, and survivorship. With the tactics of trade-off between growth versus reproduction, quantity versus quality of offspring, organisms may maximize the benefits by allocating limited resources and energy towards growth, maintenance, reproduction, raising offspring to independence and avoiding death, even under good conditions [1]. So these tradeoffs are keys to understanding the diversity of life histories, the pattern of population dynamics, the ecological strategies and evolutionary adaptation of living beings to changing environments in the field [2,3]. Recently, it has been proposed that oxidative stress is the mediator of trade-offs between survival and reproduction. Under normal environmental conditions, oxidative stress can be induced endogenously by reproduction, resulting in reduced survival as a cost. Alternatively, exogenous oxidative stress generated under adverse conditions will decreased the 
reproduction for having to invest more resources into somatic maintenance, such as the protection and repair of biomolecules damaged by overproduced reactive oxygen species (ROS) derived from oxidative attack, which should enhance survival and longevity, but at the expense of reduced fecundity and population growth [4].

With the long-term evolving, organisms have developed a set of integrated protection system, that is, the enzymatic antioxidant defense system, superoxide dismutase (SOD) and catalase (CAT) are the key members involved in this mechanism, which can be used to detoxify and remove excessively intracorporal ROS against oxidative stress [5-7]. Theoretically, for counteracting the oxidative nature of peroxides and other radicals in response to diverse environmental stressors, organisms most certainly upregulate various antioxidases to decrease the possible damage caused by adversity $[6,8]$.

Ultraviolet radiation is an important case of exogenous factor that is ecologically relevant for smallbodied invertebrates [9]. Over the past few decades, it has been well demonstrated that nature ultravioletB (UV-B) radiation increased significantly with the continuing depletion of stratospherico zone, which has becoming one of the grave concerns and most striking global changes $[10,11]$. There is growing evidence that adverse biological effects of ambient ultraviolet radiation exposure occur in not only marine but also freshwater ecosystem at different trophic levels [11, 12], involving algae [13], rotifers [14, 15], copepods $[16,17]$, cladocerans [18], shrimps [19, 20] and fishes [21]. In all cases, UVR was found to harm the organisms in question by damaging DNA directly at the molecular level and affect fitness at the individual and population levels [22]. In terms of the former case, excessive UVR may cause oxidative stress by generating ROS that are highly reactive molecules and can directly damage DNA, lipids and proteins, resulting in the elevated antioxidant enzymatic activity and linking to modulation of the expression of DNA repair-related genes as an efficient defense mechanism [23]. For the latter, UV radiation acts as a stressor for several physiological processes that lead to reduced survival and limited reproduction capacity, associating with detrimental effects on life cycle parameters and population growth of small-sized organisms [24-26].

Taking into account the sensitivity of zooplankton to ambient ultraviolet radiation, an increasing number of works have been focusing on the negative effects of increased UV-B radiation on zooplankton $[6,11$, 22]. The bdelloid rotifer, a kind of ancient asexually invertebrate, is the largest metazoan group that reproduces only through parthenogenesis, simultaneously notorious for the features of anhydrobiotic capability and horizontal gene transfer [27-29]. These features are considered to be responsible for their success in adapting to most types of habitats (moss, lichens, temporary pools, soil and water), stress tolerance and having persisted asexually for millions of years [30,31]. The radio resistance in bdelloid rotifers have been reported with a ${ }^{137} \mathrm{Cs}$ source, which indicated that reproduction of the bdelloids Adineta vaga and Philodina roseola is much more resistant to ionizing radiation (IR) than that of monogonont rotifer, and $A$. vaga is far more resistant to IR-induced protein carbonylation than the much more radiosensitive nematode Caenorhabditis elegans [32,33]. In another study, the survival of $A$. vaga was reduced under IR stress, what could be mediated by endogenously generated oxidative stress induced by reproduction [4]. When exposing $P$. roseola to UVB radiation, it appeared to shield itself from 
DNA damage through uncharacterized UV-absorbing compounds, but it was largely impossible to repair UVB-induced damage. UV-irradiation had a significant negative impact on the reproductive output of $P$. roseola, but was shown to have no significant effects on monogonont rotifer Brachionus rubens [34]. The above incongruous founding could be attributed to the type of radiation and the intensity and dose they were exposed to. Therefore, further investigations are needed with the respects of the effects of exposure to incident UV-B on the reproduction, survival and defense system in bdelloid rotifers.

Rotaria rotatoria is a conventional bdelloid rotifer species, which offers an advantageous model for investigating the ecological consequences of enhanced UV-B. Given the strong tolerance of bdelloid rotifer to environmental stressors, such as IR radiation [32, 33], we hypothesized that $R$. rotatoria could also hold the ability to tolerate significant UV radiation, and this capacity may be associated with the trade-off strategies among life historic components. In aquatic ecosystems, the tolerance and resistance of rotifer to ultraviolet radiation could be varied depending on the culture volume, radiation intensity and duration. With this study, we examined the radiation lethality of UV-B (280 to $400 \mathrm{~nm}$ ) under different culture system, the responses of population growth and fecundity of the $R$. rotatoria to the incident UVR, and measure the levels of anti-oxidant system of $R$. rotatoria under adverse conditions. We aimed to (1) detect the acute lethal effects of UVR to bdelloid rotifer; (2) estimate the ecological effects of harmful UVR on bdelloid rotifers; and (3) explore the responses of antioxidant system in bdelloid rotifers against UV radiation toxicity.

\section{Results}

\section{The lethal effects of UV-B radiation}

Under different intensities of UV-B radiation, all treatments caused lethal effects on $R$. rotatoria, and the time for the rotifers to die as well as all the rotifers have died moved in advance with the increasing of radiation intensity. The multiple comparisons showed that the radiation duration at the half death of rotifers (semi-lethal exposure time, $\mathrm{LT}_{50}$ ) decreased significantly with the enhancing of radiation intensity at the same culture volumes, which indicated the rotifers are more sensitive to the high intensity of UVR. While comparing the lethal dose (semi-lethal dose, $L_{50}$ ) in terms of dose, the regularity in lethal effects was not obvious. As the culture volume increases, the lethal effect of UVR on rotifers was weakened, and the $L T_{50}$ and $L D_{50}$ of rotifers increased at the same radiation intensity (Fig. 1).

\section{Effect of UV-B radiation treatment on the life history parameters of the rotifers}

The one-way ANOVA showed that all life table parameters in $R$. rotatoria (JP, RP, longevity and offspring) were affected significantly by the UV-B radiation treatments $(P<0.001)$ (Additional file 1: Tab. S1). By multiple comparisons, the rotifers delayed their first reproductive time (JP), and shortened their reproductive period (RP) and longevity with the increasing of radiation dose. The fecundity (offspring) was significant inhibited by UV-B radiation. By regression analysis, the significant dose-response 
relationships between the UV-B radiation and life table parameters were established with linear regression (Fig. 2).

Throughout the experimental period, the age-specific survivorships $\left(I_{x}\right)$ declined earlier after different doses irradiation treatment compared with the control group, that means the time for the rotifers to die was advanced (Additional file 2: Fig. S1). At the radiation-free condition, the rotifers began to die on the 14th day and died entirely on the 36th day. As comparison, the rotifers started to decline on the 11th, 5th, 6th, 5 th, 5 th, 4 th , 4th day at $0.012,0.024,0.036,0.048,0.060,0.072,0.084 \mathrm{~kJ} / \mathrm{m}^{2}$, then these groups survived for another $35 d, 41 d, 35 d, 31 d, 21 d, 23 d$ and $13 d$, respectively.

With regard to the age-specific fecundities $\left(m_{x}\right)$, the reproduction peak of the rotifers was 1.63 at 4 th day for the control group, while the other peaks were 1.42, 1.21, 0.92, 0.78, 0.45, 0.44 and 0.29, at 4th day, 4th day, 5th day, 6th day, 6th day, 7th day and 8th day respectively, which indicated the occurrence of these peaks delayed gradually and the peaks decreased with the strengthening of UV-B radiation (Fig. 3).

\section{Population Growth Of The Rotifers}

During the first 4 days of the experiment, there was no significant difference in population density between the treatment and control groups. However, with the extension of the irradiation duration, the population densities exposed to the radiation dose of $0.048 \mathrm{~kJ} / \mathrm{m}^{2}$ and $0.096 \mathrm{~kJ} / \mathrm{m}^{2}$ were much lower than that of the control group, and from the 16th day, the population density of the rotifers in the $0.012 \mathrm{~kJ} / \mathrm{m}^{2}$ UVR treatment was higher than that of the control group. When the experiment was carried out on the 40th day, the entire population of the $0.096 \mathrm{~kJ} / \mathrm{m}^{2}$ treatment group was extinct. Since the treatment groups at the highest radiation dose $\left(0.192 \mathrm{~kJ} / \mathrm{m}^{2}\right.$ and $\left.0.384 \mathrm{~kJ} / \mathrm{m}^{2}\right)$ did not increase and all died on the 11th day, the processing of the experimental data did not include the two groups (Fig. 4).

In addition, the UV-B radiation had a significant effect on the maximum population density of the rotifers $(P<0.001)$. The maximum population density of rotifers in the $0.012 \mathrm{~kJ} / \mathrm{m}^{2}$ treatment group was the highest, reaching $1176 \mathrm{ind} . / \mathrm{ml}$. Compared with the control group, there was no significant difference in the maximum population density of the rotifers in the $0.024 \mathrm{~kJ} / \mathrm{m}^{2}$ treatment group, and the maximum population densities of the two groups with the higher radiation dose $\left(0.048 \mathrm{~kJ} / \mathrm{m}^{2}\right.$ and $\left.0.096 \mathrm{~kJ} / \mathrm{m}^{2}\right)$ were much lower than the control group (Fig. 5). As the radiation dose increased, the population growth rates of the treatment groups gradually decreased and were smaller than the control group (Fig. 5).

\section{Antioxidant Enzyme Activities}

After treatment with different doses of UV-B radiation, the superoxide dismutase activity in rotifers was significantly higher than that of the control group $(P<0.05)$. With the increase of radiation dose, the activity of SOD enzyme increased first and then decreased. When the radiation dose was $0.72 \mathrm{~kJ} / \mathrm{m}^{2}$, the 
SOD activity was the highest, and the peak was $66.35 \mathrm{U} / \mathrm{mgprot}$, and it was significantly different from other experimental groups $(P<0.05)$ (Fig. 6).

After treatments with low doses of UV-B radiation $\left(0.36 \mathrm{~kJ} / \mathrm{m}^{2}\right.$ and $\left.0.72 \mathrm{~kJ} / \mathrm{m}^{2}\right)$, there was no significant difference in catalase activity between the treatments and the control group $(P>0.05)$. However, with the further increase in radiation dose, higher doses of UV-B radiation $\left(1.44 \mathrm{~kJ} / \mathrm{m}^{2}\right.$ and $\left.2.16 \mathrm{~kJ} / \mathrm{m}^{2}\right)$ significantly weakened the activity of the CAT enzyme. When the radiation dose was $0.72 \mathrm{~kJ} / \mathrm{m}^{2}$, the CAT activity was the highest with a peak of $10.44 \mathrm{U} /$ mgprot (Fig. 6).

\section{Discussion}

UV-B radiation is an environmental stressor for almost all aquatic trophic levels, from primary producers, zooplankton, crustaceans, amphibians, corals to fishes [35-38]. The effects of UV-B may not only act at the micro-level like inducing DNA mutation and altering enzyme activity, but also at the phenotypic attributes including affecting organismal survival, growth, motility, photosynthesis and reproduction [39, 40]. Therefore, UV radiation is a potential driving force for zooplankton community structure and population dynamics in ecosystem [12]. In the present study, a coincident conclusion showed that the survivorship of $R$. rotatoria was adversely affected by the UV-B radiation. The highest value of $24 \mathrm{~h}-\mathrm{LD}_{50}$ measured by the acute toxicity test was $4.5305 \mathrm{~kJ} / \mathrm{m}^{2}$ with the radiation intensity of $0.03 \mathrm{~mW} / \mathrm{cm}^{2}$ in the $30-\mathrm{ml}$ test volume. The $24 \mathrm{~h}-\mathrm{LD}_{50}$ value of UV-B has been reported for a variety of studies. For example, similar to our findings, Feng et al. [41] found that the $24 \mathrm{~h}-\mathrm{LD}_{50}$ value of B. plicatilis and B. urceus was $4.393 \mathrm{~kJ} / \mathrm{m}^{2}, 5.856 \mathrm{~kJ} / \mathrm{m}^{2}$ respectively in the radiation intensity of $0.05 \mathrm{~mW} / \mathrm{cm}^{2}$. Li et al. [42] also evaluated the $24-\mathrm{LD}_{50}$ value of adult males of Schmacheria inopinus was $5.77 \mathrm{~kJ} / \mathrm{m}^{2}$, as well as the $48 \mathrm{~h}$ $\mathrm{LD}_{50}$ value of adult females was $5.04 \mathrm{~kJ} / \mathrm{m}^{2}$. However, a much higher $24 \mathrm{~h}-\mathrm{LD}_{50}$ was reported for $B$. koreanus [37], with a value as high as $24.6 \mathrm{~kJ} / \mathrm{m}^{2}$ in $4-\mathrm{ml}$ working volume (no radiation intensity displayed). Such differences may further attribute to the species specificity, individual ages and physiological status, and other processes which could regulate the responses of anti-oxidant system and repair mechanisms to UVR injuries [43].

The effects of UV-B on organisms may be affected by the difference in experimental conditions, such as UV-B wavelengths, ultraviolet intensities and culture system volume. The semi-lethal time $\left(\mathrm{LT}_{50}\right)$ of the copepod Calanus sinicus was $30.47 \mathrm{~h}, 2.86 \mathrm{~h}, 1.96 \mathrm{~h}$ at the radiation intensity of $0.2 \mathrm{~mW} / \mathrm{cm}^{2}$, $0.3 \mathrm{~mW} / \mathrm{cm}^{2}$, and $0.5 \mathrm{~mW} / \mathrm{cm}^{2}$, separately [44]. Consistent with these results, the radiation duration within which approaching to the half death of $R$. rotatoria decreased significantly with the increasing of radiation intensity at the same culture volumes in this study, which indicated the rotifers are more sensitive to the high intensity of UVR. In addition, the persistence of tolerance (evaluating by $\mathrm{LT}_{50}$ ) in rotifer to stress was playing a more vital role than the radiation dose $\left(\mathrm{LD}_{50}\right)$ in survival. As the culture volume increases, the lethal effect of UVR on rotifers was weakened, which could due to the variety of permeability of UVR for different working volumes. 
During the last few decades, a growing cognition considering the organism as an adapted complex has increased awareness of adaptive evolution not only at the biochemical, physiological, and morphological level, but also at the life history level [45]. The present study was carried out to explore the effects of UV-B radiation on the life history of the rotifer, and further inspect whether there are trade-off strategies among life historic components. According to the results, we conceived a presumptive model (Fig. 7) about the changes of testing parameters under UV-B radiation. From the results, the fecundity and survivorship of rotifers were negative affected remarkably by UVR treatment. Compared with the control group, the fecundity of rotifers exposed to UV-B radiation was significantly decreased, which was validated by the cumulated number of offspring and the age-specific fecundities $\left(m_{x}\right)$. The greater the radiation dose, the more obvious the inhibitory effects. Our results are consistent with some previous studies which indicated exposure to UV radiation had a significant effect on the abundance and/or reproduction of four rotifers, two cladocerans and one copepod [46], and UV-B effectively inhibited B. calyciflorus reproduction and reduced ingestion by up to $90 \%$ [47]. Possibly, the reproductive system of rotifers could be destroyed by the high dose of UV-B radiation. Alternatively, animals may have to invest more energy to maintain basal living processes to ensure survivorship, which in turn comes at the cost of reductions in reproduction (Fig. 7). In addition, the rotifers in this study prolonged their first reproductive time (JP), and shortened their reproductive period (RP) and longevity with the increasing of radiation dose, which also could be the key factor causing the decrease of reproduction. In the experiments about the effects of the thiophanate-methyl on the reproduction and survival in B. calyciflorus, as well as the studies for impacts of the deltamethrin on experimental population dynamics of $B$. calyciflorus $[48,49]$, the extension of juvenile period was regarded as the major cause resulted in lower $m_{x}$. This is in line with Pourriot [50], who considered that the $\mathrm{m}_{\mathrm{x}}$ more depended on the duration of juvenile period and embryonic development during the period of parthenogenetic reproduction in rotifers, rather than $R_{0}$.

In the population growth experiment, the rotifers all died at the highest radiation dose $\left(0.192 \mathrm{~kJ} / \mathrm{m}^{2}\right.$ and $0.384 \mathrm{~kJ} / \mathrm{m}^{2}$ ), which suggested high UV radiation has significant lethal effect, by probably causing the DNA damage and cell degradation $[37,41]$. On the 16th day, the population density under the low UVR dose of $0.012 \mathrm{~kJ} / \mathrm{m}^{2}$ began to be higher than that of control group, and similarly, the maximum population density in $R$. rotatoria was highest at $0.012 \mathrm{~kJ} / \mathrm{m}^{2}$, and then decreased significantly with increasing UV-B radiation dose, which suggested that low doses of UV-B radiation can stimulate the reproduction of rotifers to some degree. However, high doses of radiation have different levels of inhibition on rotifers. The stimulation effects that was explained as hormesis is also occurred in zooplankton under the other stress [51, 52]. Low dose of toxic chemicals below the damage threshold can stimulate the growth of organisms, and trigger physiological regulation to enter metabolic stasis in response to severe environmental stress. Further studies are needed about the specific biological mechanisms $[53,54]$.

The cell damages stated above are often caused by a great deal of free radicals produced under the stress of exoteric adverse factors, accordingly the anti-oxidant system in organisms will be accelerated for defense. Of which, the SOD and CAT are the two important anti-oxidant enzymes that can response to 
stresses rapidly including eliminate the reactive oxygen species $[55,56]$. In the present study, the two enzymes in the $R$. rotatoria have the coincident response to UVR stress with a pattern of rising first and then falling. The enzyme SOD has higher level of content and more sensitive to low UVR than CAT. The similar results also present in the phytoplankton under the UVR stresses [57]. So, it follows that the antioxidant system plays a very important role when exposed to adverse stress, and the repairing effects occur as the positive response to low dose of UVR, while the enzyme activities decline with the increasing of radiation dose, which could be attributed to the damage of enzymes to varying levels. Rautio \& Tartarotti [6] also found a negative relationship between CAT and solar radiation which indicated this enzyme was inhibited or inactivated by UVR. The fluctuating patterns of anti-oxidant enzyme activity can reveal the ability of various organisms to cope with environmental stress to a certain extent.

\section{Conclusions}

There were significant responses of the survival, fecundity, duration of development and the anti-oxidant enzyme system in $R$. rotatoria to UV-B radiation in different intensities and doses. The lethal effects of UV-B radiation to organisms depends not only on the conditions they exposed to, like as intensity and time of exposure, but also combination of factors namely, the type and effectiveness of the strategy they employ to cope with the changed environment. The species specificity, individual ages and physiological responses also could be the regulating factors under the UV-B stresses, also in this case there was the strategy of energy trade-off between reproduction and survival in rotifers. At low dose of UVR, rotifers defend against the radiation stress by increasing the anti-oxidant enzyme activities, while high doses of radiation have significant inhibition effects on rotifers.

\section{Methods}

\section{Rotifer Collection And Culture}

The $R$. rotatoria was sampled at a pond near Jing village $\left(31^{\circ} 73^{\prime} 67^{\prime \prime} \mathrm{N}, 118^{\circ} 33^{\prime} 72^{\prime \prime} \mathrm{E}\right)$ in Hexian County, Anhui Province, China. Then the rotifers were isolated individually under microscope and cultured in the $28^{\circ} \mathrm{C}$ constant temperature incubator. The EPA medium, used to maintain rotifers, was freshly prepared by dissolving $96 \mathrm{mg} \mathrm{NaHCO}_{3}, 60 \mathrm{mg} \mathrm{CaSO}_{4}, 60 \mathrm{mg} \mathrm{MgSO}{ }_{4}$ and $4 \mathrm{mg} \mathrm{KCl}$ in 1 liter of distilled water (pH 7.4-7.8) [58]. The algae Scenedesmus obliquus was grown semi-continuously at $28^{\circ} \mathrm{C}$ in an illumination incubator using HB-4 medium [59] and stored at $4^{\circ} \mathrm{C}$ for using as rotifer foodstuff after centrifuging in exponential growth. We estimated the density of the algal concentrate by a hemocytometer.

\section{UV-B radiation}

The ultraviolet radiation was supplied with UV-B lamps (wavelength range of 280 to $312 \mathrm{~nm}$; UVB-308NM, Shengzheng Guanya Optoelectronic Technology Co., Ltd.). The intensity of UVR was measured by a UV-B radiometer manufactured by Beijing Normal University. In order to ensure that rotifers were under the same UVR intensity, they were placed on the low-speed rotating platform directly below UV-B lamps. 
Furthermore, to obtain the stable intensity of UV light source, the lamp was turned on 30 minutes before the experiment began. At a certain radiation intensity, the animals will be treated with different doses of UVR by exposing them under UV-B radiation for different time.

\section{Mortality Test}

Before starting the experiments, the rotifers were pre-cultured at $28^{\circ} \mathrm{C}$ for at least one month to minimize maternal effects. To obtain the value for $50 \%$ of the lethal dose (semi-lethal dose, $L D_{50}$ ) upon UV-B radiation in three culture volumes of $0.5 \mathrm{ml}, 6 \mathrm{ml}$ and $30 \mathrm{ml}$, we introduced 10 neonates (less than $6 \mathrm{~h}$ old) into different culture vessels $(0.5-\mathrm{ml}$ culture plates, $6-\mathrm{ml}$ transparent jars and $30-\mathrm{ml}$ beakers respectively) which contained EPA medium with $1.0 \times 10^{6}$ cells $/ \mathrm{mL}$ of $S$. obliquus and exposed them to constantly UV-B radiation at the intensity of $0.01,0.02,0.03,0.04$ and $0.05 \mathrm{~mW} / \mathrm{cm}^{2}$. In total, 540 neonates were tested (10 neonates/treatment $\times 3$ replicates $\times 3$ volumes $\times 5$ UVR intensities, and one control group). The culture vessels were shaded with a quartz cover to allow UV-B transparency and to prevent evaporation during UVB exposure. Thereafter the survival of rotifers was checked every half hour under a stereomicroscope until each individual of every cohort died. Then the $L D_{50}$ values were respectively derived following the probit method [60].

\section{Life History Experiment}

According to the lethal effect assay, to ensure that the rotifer could complete the whole life history, the radiation dose in this experiment were set to $0,0.012,0.024,0.036,0.048,0.060,0.072,0.084 \mathrm{~kJ} / \mathrm{m}^{2}$ at the intensity of $0.01 \mathrm{~mW} / \mathrm{cm}^{2}(0,2,4,6,8,10,12$ and 14 min radiation duration respectively each day). After preculture of one month at $28^{\circ} \mathrm{C}$, the neonates (less than $6 \mathrm{~h}$ old) were separated indiscriminately and transferred into each well (working volume, $0.5 \mathrm{ml} \mathrm{EPA} \mathrm{with} 1.0 \times 10^{6}$ cells $/ \mathrm{mL}$ of S. obliquus) of 24well culture plate. The 24 individuals were inspected for each radiation dose, so 384 neonates in total were prepared and then exposed to UV-B radiation. After UVR treatment, we checked the rotifers every $12 \mathrm{~h}$ during the first two days, followed by observation every $6 \mathrm{~h}$ until each infant grow into an adult and produced the first offspring. Then they were examined every $12 \mathrm{~h}$ until the end of experiment. Meanwhile, the time and number of the offspring produced and the death time of female adult were recorded. During the life table experiment, the surviving mature females were exposed to UV-B radiation at the same time every day, observed and transferred to clean culture plates with fresh food and medium, and the counted neonates were removed.

\section{Population growth of $\mathrm{R}$. rotatoria}

At the intensity of $0.02 \mathrm{~mW} / \mathrm{cm}^{2}$, the UVR dose was designed to be 0 (control), $0.012,0.024,0.048,0.096$, 0.192 and $0.384 \mathrm{~kJ} / \mathrm{m}^{2}$ in the population growth experiment $(0,1,2,4,8,16$ and 32 min radiation duration respectively each day). Before the formal experiment, $R$. rotatoria was pre-cultured at $28^{\circ} \mathrm{C}$ for 
one month. After that, 252 alive neonates (less than $6 \mathrm{~h}$ old) were collected and placed equally into 21 glass jars ( 7 treatments $\times 3$ replicates) containing $6 \mathrm{ml}$ of EPA medium with $1.0 \times 10^{6} \mathrm{cell} / \mathrm{ml}$ of algae food. These organisms were exposed to UV-B radiation at the same time every day until the end of experiment. To avoid the disadvantageous effects of UVR on algae cells, S. obliquus at the density of 1.0 $\times 10^{6} \mathrm{cells} / \mathrm{ml}$ was fed to rotifers after the radiation treatment once a day. The rotifers were maintained in a $28^{\circ} \mathrm{C}$ incubator without light, and counted once every day before the radiation treatment in the first few days, while sampling counted when the population is large.

\section{Determination Of Catalase And Superoxide Dismutase Activity}

The radiation dose was designed to be 0 (control), $0.36,0.72,1.44$ and $2.16 \mathrm{~kJ} / \mathrm{m}^{2}$ at the intensity of $0.02 \mathrm{~mW} / \mathrm{cm}^{2}$. To meet the demand for detecting the enzyme activity, adequate numbers of rotifer was necessary, and 90 beakers $(\approx 3000$ individuals in 30-ml beakers) were dealt with in total ( 6 beakers/treatment $\times 5$ treatments $\times 3$ replicates). After pre-culture as stated above and starvation for one day, rotifers were exposed to the UVR $(0,0.5,1,2$ and $3 \mathrm{~h}$ radiation duration respectively). Then the rotifers were sampling counted and filtered rapidly using a plankton net (mesh size, $20 \mu \mathrm{m}$ ), washed several times with double distilled water, centrifuged, and immediately froze at $-80^{\circ} \mathrm{C}$ for use within 10 days. The rotifers on ice thawed gradually in a temperature gradient were homogenized by ultrasonication, and centrifuged at $10,000 \mathrm{~g}$ for $10 \mathrm{~min}$ at $4^{\circ} \mathrm{C}$. The supernatant containing the enzyme was collected for the enzymatic assay according to the protocols (SOD by WST-1 method: Cat. No. A0013; CAT by visible spectrometry method: Cat. No. A007-1; both manufactured by Nanjing Jiancheng Bioengineering Institute, China). The SOD and CAT activities were then measured at the absorbance of $450 \mathrm{~nm}$ and $405 \mathrm{~nm}$ using an enzyme-labeled meter at $25^{\circ} \mathrm{C}$. The soluble protein content in $R$. rotatoria was measured using Pierce ${ }^{T M}$ BCA Protein Assay Kit (Cat. No. 23227, Thermo Fisher Scientific) according to the protocol direction.

\section{Data analysis}

Statistical analysis was performed using SPSS19.0 software. All data were tested for normality using the one-sample Kolmogorov-Smirnov procedure. The homogeneity of variances was checked using Levene's test. One-way analysis of variance (ANOVA) was conducted to identify the significant effects of UVR on the lethal effects, life history parameters in rotifer, and multiple comparisons were conducted using least significant rank to identify which groups were significantly different among different radiation doses, and the significance level was set to 0.05 . Consequently, regression analysis was performed on the relationships of the dose-response.

The durations of juvenile period (JP, the time between a neonate and that producing the first baby), reproductive period (RP, the time between an adult producing the first baby and the last baby), longevity and offspring of rotifers grown at different doses of UV-B radiation were calculated depended on the 
recorded data. In the population growth experiment, the population growth rate was calculated using the

$$
\mathrm{r}=\frac{\ln N_{t}-\ln N_{0}}{t}
$$

formula , where $N_{0}$ is the initial population density $(2 \mathrm{ind} . / \mathrm{ml})$, and $N_{t}$ is the population density at time $t$ in days [61].

\section{Abbreviations}

ROS

reactive oxygen species; SOD:superoxide dismutase; CAT:catalase; UV-B:ultraviolet-B; UVR:ultraviolet radiation; IR:ionizing radiation; $\mathrm{LT}_{50}$ :semi-lethal exposure time; $\mathrm{LD}_{50}$ :lethal dose; JP:the durations of juvenile period; RP:reproductive period; ANOVA:analysis of variance.

\section{Declarations}

\section{Acknowledgements}

Not applicable.

\section{Authors' contributions}

LZ and XX planned and coordinated the study and wrote the manuscript. RH and YC collected the rotifer samples and gave assistance in life history and population growth experiments. LZ and YX contributed in data analysis and language improvement. All authors read and approved the final manuscript.

\section{Funding}

This research was funded by Natural Science Foundation of China (31872208), the grant of the China Scholarship of Council (CSC) to Xian-ling Xiang, Natural Science Foundation of Anhui Province (1708085MC79), and the Key Laboratory of Biotic Environment and Ecological Safety in Anhui Province.

\section{Availability of data and materials}

The data that support the findings of this study will be available in Dryad after obtaining the manuscript number.

\section{Ethics approval and consent to participate}

Not applicable.

\section{Consent for publication}

Not applicable. 


\section{Competing interests}

The authors declare that they have no competing interests.

\section{Author details}

${ }^{1}$ School of Ecology and Environment, Anhui Normal University, Wuhu 241000, Anhui, China. ${ }^{2}$ Collaborative Innovation Center of Recovery and Reconstruction of Degraded Ecosystem in Wanjiang Basin Co-founded by Anhui Province and Ministry of Education, Wuhu 241000, Anhui, China. ${ }^{3}$ Institute of Ecology, College of Urban and Environmental Science, and Key Laboratory for Earth Surface Processes of the Ministry of Education, Peking University, 100871, Beijing, China. ${ }^{4}$ Department of Aquatic Ecology, Netherlands Institute of Ecology (NIOO-KNAW), Droevendaalsesteeg 10, NL-6708 PB Wageningen, the Netherlands.

\section{References}

1. Norgan NG, Bogin B, Cameron N. Nutrition and Growth. In: Cameron N, Bogin B, editors. Human Growth and Development (2nd Ed.). Bosto: Academic Press; 2012. p. 123-152.

2. Bednekoff PA. Predation Risk and Life Histories. In: Breed MD, Moore J, editors. Encyclopedia of Animal Behavior. Oxford: Academic Press. 2010. p. 283-287.

3. Martin JGA, Bize P. Life History. In: Vonk J, Shackleford TK, editors. Encyclopedia of Animal Cognition and Behavior. New York: Springer. 2018.

4. Latta LC, Tucker KN, Haney RA. The relationship between oxidative stress, reproduction, and survival in a bdelloid rotifer. BMC Ecol. 2019; 19: 7. https://doi.org/10.1186/s12898-019-0223-2.

5. Barata C, Varo I, Navarro JC, Arun S, Porte C. Antioxidant enzyme activities and lipid peroxidation in the freshwater cladoceran Daphnia magna exposed to redox cycling compounds. Comp Biochem Physiol C: Pharmacol Toxicol. 2005; 140: 175-186. https://doi.org/10.1016/j.cca.2005.01.013.

6. Rautio M, Tartarotti B. UV radiation and freshwater zooplankton: damage, protection and recovery. Freshw Rev. 2010; 3: 105-131. https://doi.org/10.1608/FRJ-3.2.157.

7. Snell TW, Fields AM, Johnston RK. Antioxidants can extend lifespan of Brachionus manjavacas (Rotifera), but only in a few combinations. Biogerontology. 2012; 13: 261-275. https://doi.org/10.1007/s10522-012-9371-x.

8. Borgeraas J, Hessen DO. UV-B induced mortality and antioxidant enzyme activities in Daphnia magna at different oxygen concentrations and temperatures. J Plankton Res. 2000; 22: 1167-1183. https://doi.org/10.1093/plankt/22.6.1167.

9. Heine KB, Powers MJ, Kallenberg C, Tucker VL, Hood WR. Ultraviolet irradiation increases size of the first clutch but decreases longevity in a marine copepod. Ecol Evol. 2019; 9: 9759-9767. https://doi.org/10.1002/ece3.5510. 
10. Robinson SA, Erickson DJ. Not just about sunburn - the ozone hole's profound effect on climate has significant implications for Southern Hemisphere ecosystems. Glob Change Biol. 2015; 21: 515-527. https://doi.org/10.1111/gcb.12739.

11. Peng SJ, Liao HX, Zhou T, Peng SL. Effects of UVB radiation on freshwater biota: a meta-analysis. Global Ecol Biogeogr. 2017; 26: 500-510. https://doi.org/10.1111/geb.12552.

12. Häder DP, Kumar HD, Smith RC, Worrest RC. Effects of solar UV radiation on aquatic ecosystems and interactions with climate change. Photoch Photobio Sci. 2007; 6: 267-285. https://doi.org/10.1039/B700020K.

13. Sun $Y$, Zhang $X$, Zhang L, Huang $Y$, Yang Z, Montagnes D. UVB radiation suppresses antigrazer morphological defense in Scenedesmus obliquus by inhibiting algal growth and carbohydrateregulated gene expression. Environ Sci Technol. 2020; 54: 4495-4503. https://doi.org/10.1021/acs.est.0c00104.

14. Luijckx P, Ho EKH, Stanić A, Agrawal AF. Mutation accumulation in populations of varying size: large effect mutations cause most mutational decline in the rotifer Brachionus calyciflorus under UV-C radiation. J Evolution Biol. 2018; 31: 924-932. https://doi.org/10.1111/jeb.13282.

15. Colangeli P, Schlägel UE, Obertegger U, Petermann JS, Tiedemann R, Weithoff G. Negative phototactic response to UVR in three cosmopolitan rotifers: a video analysis approach. Hydrobiologia. 2019; 844: 43-54. https://doi.org/10.1007/s10750-018-3801-y.

16. Puthumana J, Lee MC, Park JC, Kim HS, Hwang DS, Han J, Lee JS. Ultraviolet B radiation induces impaired lifecycle traits and modulates expression of cytochrome P450 (CYP) genes in the copepod Tigriopus japonicus. Aquat Toxicol. 2017; 184: 116-122. https://doi.org/10.1016/j.aquatox.2017.01.011.

17. Laspoumaderes C, Navarro MB, Souza MS, Modenutti B, Balseiro E. Effect of ultraviolet radiation on clearance rate of planktonic copepods with different photoprotective strategies. Int Rev Hydrobiol. 2019; 104: 34-44. https://doi.org/10.1002/iroh.201801960.

18. Fernández CE, Rejas D. Effects of UVB radiation on grazing of two cladocerans from high-altitude Andean lakes. PLoS One. 2017; 12: e0174334. https://doi.org/10.1371/journal.pone.0174334.

19. Harbi MA, Chithambaran S, Salama A. Effect of UV-B solar radiation on plankton community and Bcarotene of pacific white shrimp, Litopenaeus vannamei. J King Abdulaziz Univ-Sci. 2018; 21: 35-42. https://doi.org/10.4197/Mar.27-1.4.

20. Marcoval MA, Pan J, Díaz AC, Espino L, Arzoz NS, Fenucci JL. Dietary photoprotective compounds ameliorate UV tolerance in shrimp (Pleoticus muelleri) through induction of antioxidant activity. $\mathrm{J}$ World Aquacult Soc. 2018; 49: 933-942. https://doi.org/10.1111/jwas.12482.

21. Lawrence KP, Young AR, Diffey BL, Norval M. The impact of solar ultraviolet radiation on fish: Immunomodulation and photoprotective strategies. Fish Fish. 2020; 21: 104-119. https://doi.org/10.1111/faf.12420.

22. Grad G, Williamson CE, Karapelou DM. Zooplankton survival and reproduction responses to damaging UV radiation: A test of reciprocity and photoenzymatic repair. Limnol Oceanogr. 2001; 46: 
584-591. https://doi.org/10.4319/lo.2001.46.3.0584.

23. Kim BM, Rhee JS, Lee KW, Kim MJ, Shin KH, Lee SJ, Lee YM, Lee JS. UV-B radiation-induced oxidative stress and p38 signaling pathway involvement in the benthic copepod Tigriopus japonicus. Comp Biochem Physiol C: Pharmacol Toxicol. 2015; 167: 15-23.

https://doi.org/10.1016/j.cbpc.2014.08.003.

24. Malloy KD, Holman MA, Mitchell D, Detrich HW. III. Solar UVB-induced DNA damage and photoenzymatic DNA repair in Antarctic zooplankton. P Natl Acad Sci USA. 1997; 94: 1258-1263. https://doi.org/10.1073/pnas.94.4.1258.

25. Wong CY, Teoh ML, Phang SM, Lim PE, Beardall J. Interactive effects of temperature and UV radiation on photosynthesis of Chlorella strains from polar, temperate and tropical environments: differential impacts on damage and repair. PLoS ONE. 2015; 10: e0139469. https://doi.org/10.1371/journal.pone.0139469.

26. Han J, Puthumana J, Lee MC, Kim S, Lee JS. Different susceptibilities of the Antarctic and temperate copepods Tigriopus kingsejongensis and T. japonicus to ultraviolet (UV) radiation. Mar Ecol Prog Ser. 2016; 561: 99-107. https://doi.org/10.3354/meps11946.

27. Mark Welch DB, Meselson M. Evidence for the evolution of bdelloid rotifers without sexual reproduction or genetic exchange. Science. 2000; 288: 1211-1215. https://doi.org/10.1126/science.288.5469.1211.

28. Barraclough TG, Fontaneto D, Ricci C, Herniou EA. Evidence for inefficient selection against deleterious mutations in cytochrome oxidase I of asexual bdelloid rotifers. Mol Biol Evol. 2007; 24: 1952-1962. https://doi.org/10.1093/molbev/msm123.

29. Hespeels B, et al. Iron ladies-How desiccated asexual rotifer Adineta vaga deal with X-rays and heavy ions?. Front Microbiol. 2020; 11: 1792. https://doi.org/10.3389/fmicb.2020.01792.

30. Ricci C. Life histories of some species of Rotifera Bdelloidea. Hydrobiologia. 1983; 104: 175-180. https://doi.org/10.1007/BF00045965.

31. Flot JF, et al. Genomic evidence for ameiotic evolution in the bdelloid rotifer Adineta vaga. Nature. 2013; 500: 453-457. https://doi.org/10.1038/nature12326.

32. Gladyshev EA, Meselson M. Extreme resistance of bdelloid rotifers to ionizing radiation. $P$ Natl Acad Sci USA. 2008; 105: 5139-5144. https://doi.org/10.1073/pnas.0800966105.

33. Krisko A, Leroy M, Radman M, Meselson M. Extreme anti-oxidant protection against ionizing radiation in bdelloid rotifers. P Natl Acad Sci USA. 2012; 109: 2354-2357. https://doi.org/10.1073/pnas.1119762109.

34. Fischer C, Ahlrichs WH, Buma AGJ, van de Poll WH, Bininda-Emonds ORP. How does the 'ancient' asexual Philodina roseola (Rotifera: Bdelloidea) handle potential UVB-induced mutations? J Exp Biol. 2013; 216: 3090-3095. https://doi.org/10.1242/jeb.087064.

35. Day TA, Neale PJ. Effects of UV-B radiation on terrestrial and aquatic primary producers. Annu Rev Ecol Syst. 2002; 33: 371-396. https://doi.org/10.1146/annurev.ecolsys.33.010802.150434. 
36. Hansson L, Hylander S. Effects of ultraviolet radiation on pigmentation, photoenzymatic repair, behavior, and community ecology of zooplankton. Photoch Photobio Sci. 2009; 8: 1266-1275. https://doi.org/10.1039/B908825C.

37. Kim RO, Rhee JS, Won EJ, Lee KW, Kang CM, Lee YM, Lee JS. Ultraviolet-B retards growth, induces oxidative stress, and modulates DNA repair-related gene and heat shock protein gene expression in the monogonont rotifer, Brachionus sp. Aquat Toxicol. 2011; 101: 529-39. https://doi.org/10.1016/j.aquatox.2010.12.005.

38. Vitt S, Bakker T, Rick I. Differential investment in pre- and post-mating male sexual traits in response to prolonged exposure to ambient UVB radiation in a fish. Sci Total Environ. 2020; 712: 136341. https://doi.org/10.1016/j.scitotenv.2019.136341.

39. Häder DP. Effects of solar UV-B radiation on aquatic ecosystems. Adv Space Res. 2000; 26: 20292040. https://doi.org/10.1016/S0273-1177(00)00170-8.

40. Dahms HU, Lee JS. UV radiation in marine ectotherms: Molecular effects and responses. Aquat Toxicol. 2010; 97: 3-14. https://doi.org/10.1016/j.aquatox.2009.12.002.

41. Feng $L$, Xiao H, Wang RJ, Tang XX, Li YQ. Comparison between two species of marine rotifers for the sensitivity to UV-B radiation. Mar Environ Sci. 2006; 25: 25-28. https://doi.org/10.3969/j.issn.10076336.2006.03.007.

42. Li Y, Tang XX, Yu J, Feng L. Effects of UV-B radiation on the mortality and ingestion of Schmacheria inopinus. Period Ocean Univ China. 2006; 36: 109-113. https://doi.org/10.16441/j.cnki.hdxb.2006.s1.021.

43. Hecox-Lea BJ, Mark Welch DB. Evolutionary diversity and novelty of DNA repair genes in asexual Bdelloid rotifers. BMC Evol Biol. 2018; 18: 177. https://doi.org/10.1186/s12862-018-1288-9.

44. Tao ZC. Studies on the wave-specific influence of visible and ultraviolet light on activities of Calanus sinicus. Master Thesis, Institute of Oceanology of the Chinese Academy of Sciences. 2005.

45. Wilbur HM, Tinkle DW, Collins JP. Environmental certainty, trophic level, and resource availability in life history evolution. Am Nat. 1974; 108: 805-817. https://doi.org/10.1086/282956.

46. Persaud AD, Williamson CE. Ultraviolet and temperature effects on planktonic rotifers and crustaceans in northern temperate lakes. Freshw Biol. 2005; 50: 467-476. https://doi.org/10.1111/j.1365-2427.2005.01334.x.

47. Preston BL, Snell TW, Kneisel R. UV-B exposure increases acute toxicity of pentachlorophenol and mercury to the rotifer Brachionus calyciflorus. Environ Pollut. 1999; 106(1): 23-31. https://doi.org/10.1016/S0269-7491(99)00065-2.

48. Xi YL, Hu HY. Effect of thiophanate-methyl on the reproduction and survival of the freshwater rotifer Brachionus calyciflorus, Pallas. B Environ Contam Tox. 2003; 71: 722-728. https://doi.org/10.1007/s00128-003-0192-0.

49. Xu XP, Xi YL, Chu ZX, Chen F. Effect of deltamethrin on experimental population dynamics of freshwater rotifers Brachionus calyciflorus. Acta Zool Sin. 2005; 51(2): 251-256. https://doi.org/10.3969/j.issn.1674-5507.2005.02.009. 
50. Pourriot R. Les rotifères-biologie. In: Barnabé G. editor. Aquaculture. Paris: Tec \& Doc Lavoisier. 1986. p. 201-221.

51. Fang K. The effects of BDE-47, BDE-209 on the feeding behavior with Brachionus plicatilis and the mechanism based in the changes of digestive enzyme activity. Master Thesis, Ocean University of China. 2013.

52. Sha JJ. The toxic effects of two kinds of polybrominated diphenyl ethers (BDE-47, BDE-209) on the Brachionus plicatilis. PhD Thesis, Ocean University of China. 2015.

53. Stebbing ARD. Hormesis-the stimulation of growth by low levels of inhibitors. Sci Total Environ. 1982; 22: 213-234. https://doi.org/10.1016/0048-9697(82)90066-3.

54. Ricci C, Perletti F. Starve and survive: stress tolerance and life-history traits of a bdelloid rotifer. Funct Ecol. 2006; 20: 340-346. https://doi.org/10.1111/j.1365-2435.2006.01082.x.

55. Vega MP, Pizarro RA. Oxidative stress and defence mechanisms of the freshwater cladoceran Daphnia longispina exposed to UV radiation. J Photoch Photobio B. 2000; 54: 121-125. https://doi.org/10.1016/S1011-1344(00)00005-1.

56. Köhler H, Contreras RA, Pizarro M, Cortés-Antíquera R, Zúñiga GE. Antioxidant responses induced by UVB radiation in Deschampsia antarctica Desv. Front Plant Sci. 2017; 8: 921. https://doi.org/10.3389/fpls.2017.00921.

57. Abo-Shady AM, El-Naggar A, El-Sheekh M, Abomohra AE. Impact of UV-B radiation on antioxidant enzymes and protein electrophoretic pattern of the green alga Chlorococcum sp. Ann Microbiol. 2008; 58: 195-201. https://doi.org/10.1007/BF03175316.

58. Peltier WH, Weber $\mathrm{Cl}$. Methods for measuring the acute toxicity of effluents to freshwater and marine organisms. EPA/600/4-85/013. United States Environmental Protect Agency, Cincinnati, Ohio, USA. 1985.

59. Li SH, Zhu H, Xia YJ, Yu MJ, Lin KE, Liu KS, Yue ZC, Chen YX. The mass culture of unicellular green algae. Acta Hydrobiol Sin. 1959; 4: 462-472. http://ir.ihb.ac.cn/handle/152342/7248.

60. Finney DJ. Probit Analysis. London: Cambridge University Press. 1971.

61. Krebs CJ. Ecology: the experimental analysis of distribution and abundance. New York: Harper and Row. 1985.

\section{Figures}




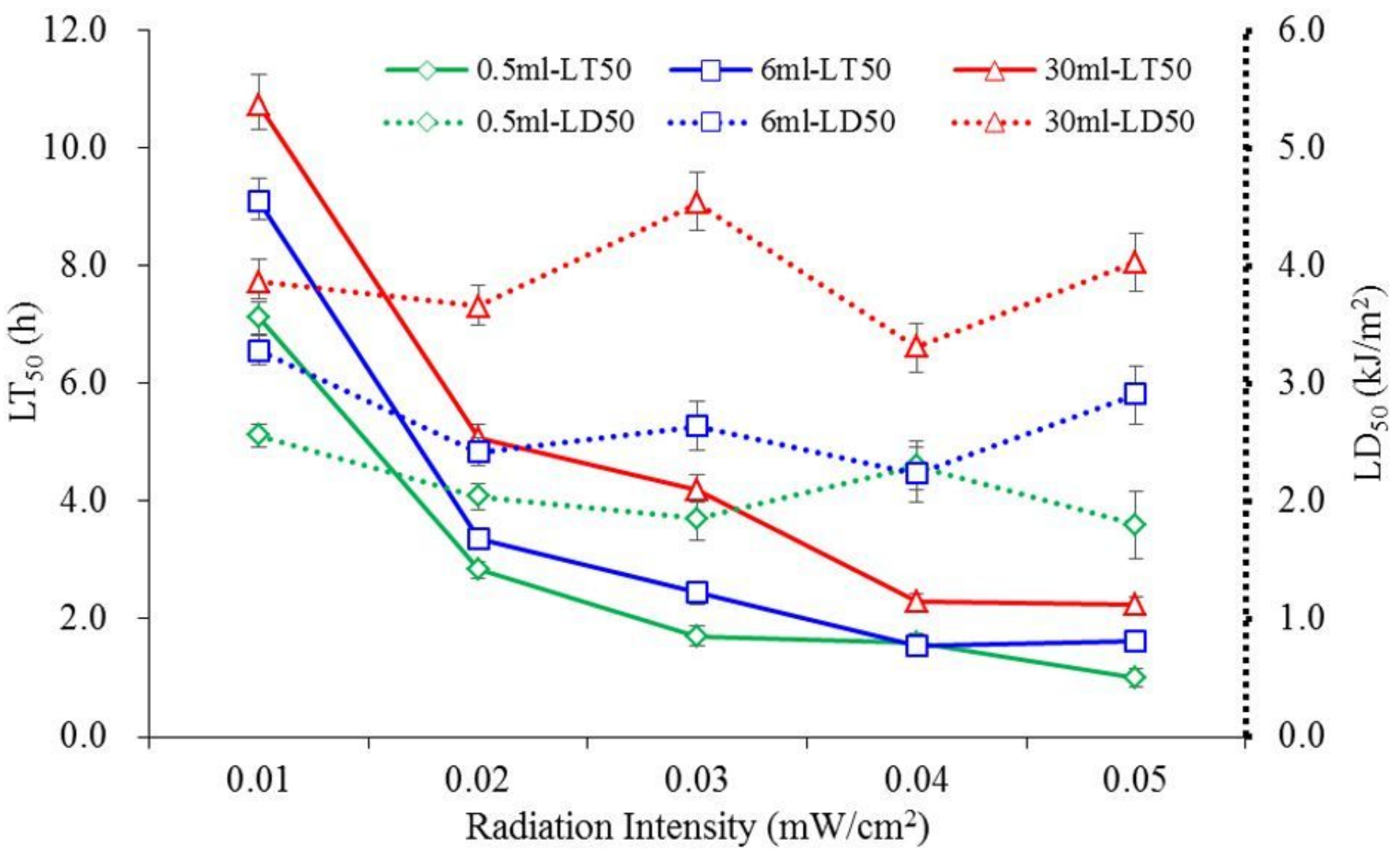

Figure 1

The semi-lethal time (LT50) and dose (LD50) of R. rotatoria in different UV-B radiation intensities and culture systems (Mean \pm SD).

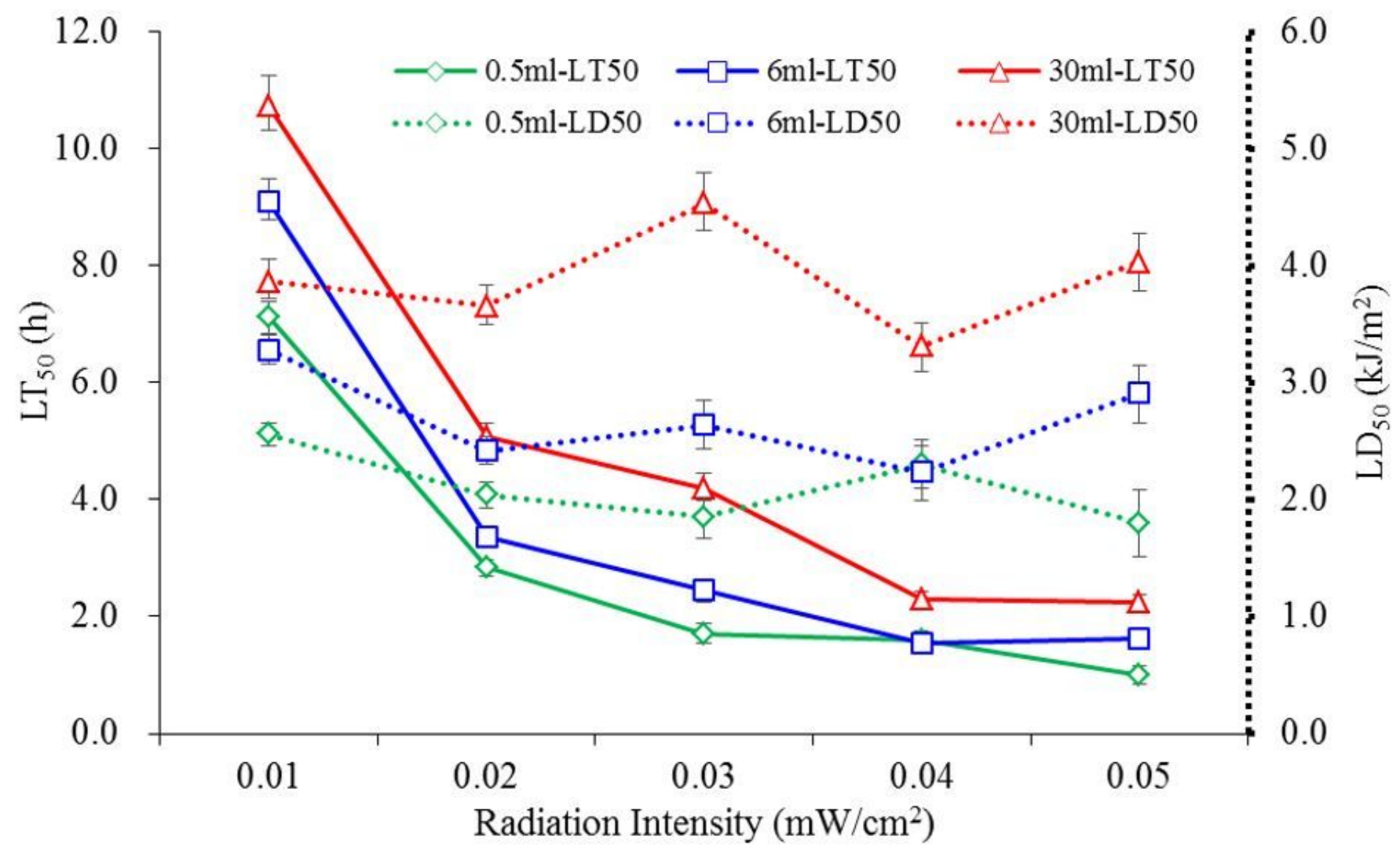


Figure 1

The semi-lethal time (LT50) and dose (LD50) of R. rotatoria in different UV-B radiation intensities and culture systems (Mean \pm SD).

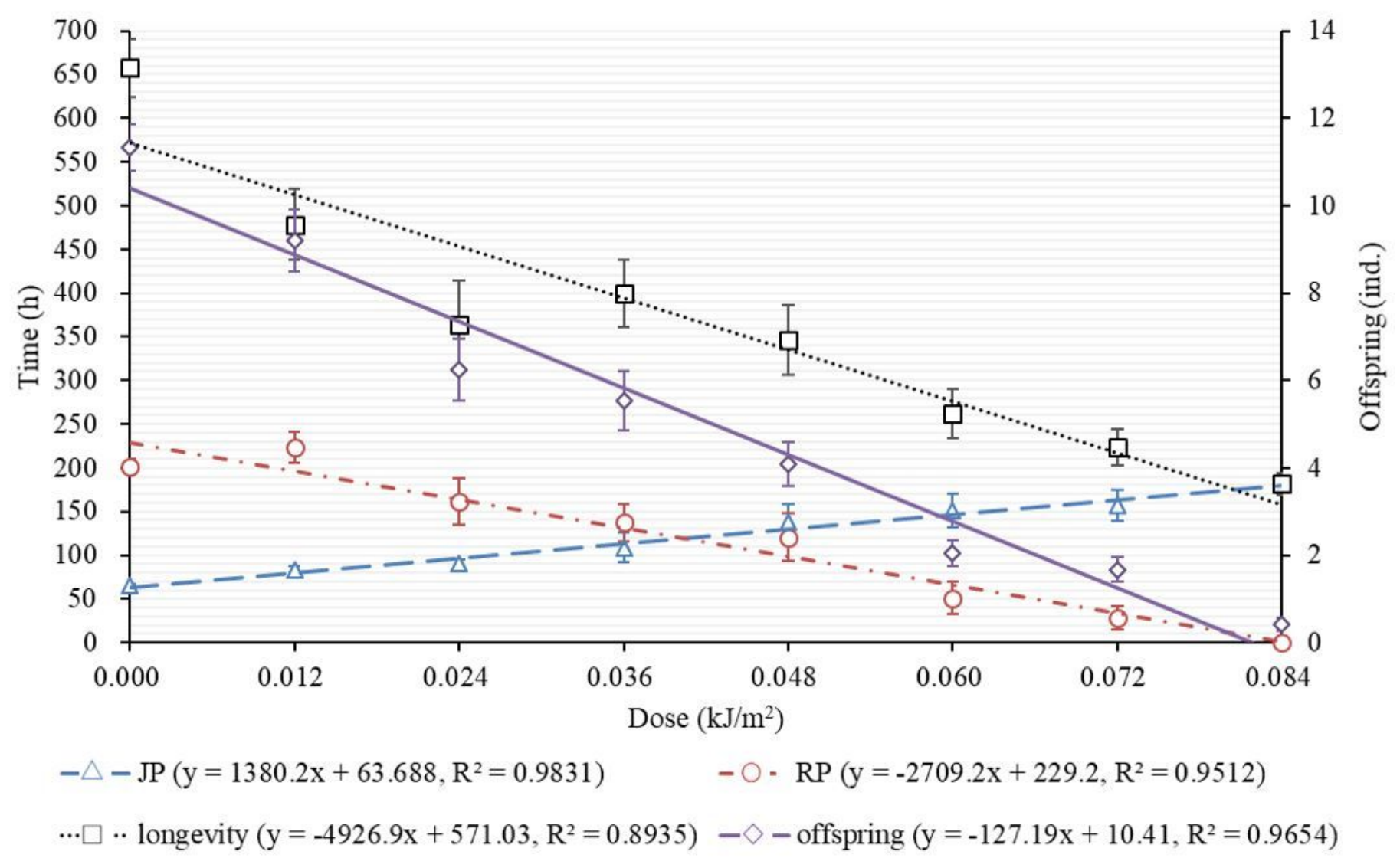

\section{Figure 2}

The life history parameters of the R. rotatoria under different radiation treatments (Mean \pm SE). (JP, the durations of juvenile period; RP, the durations of reproductive period) 


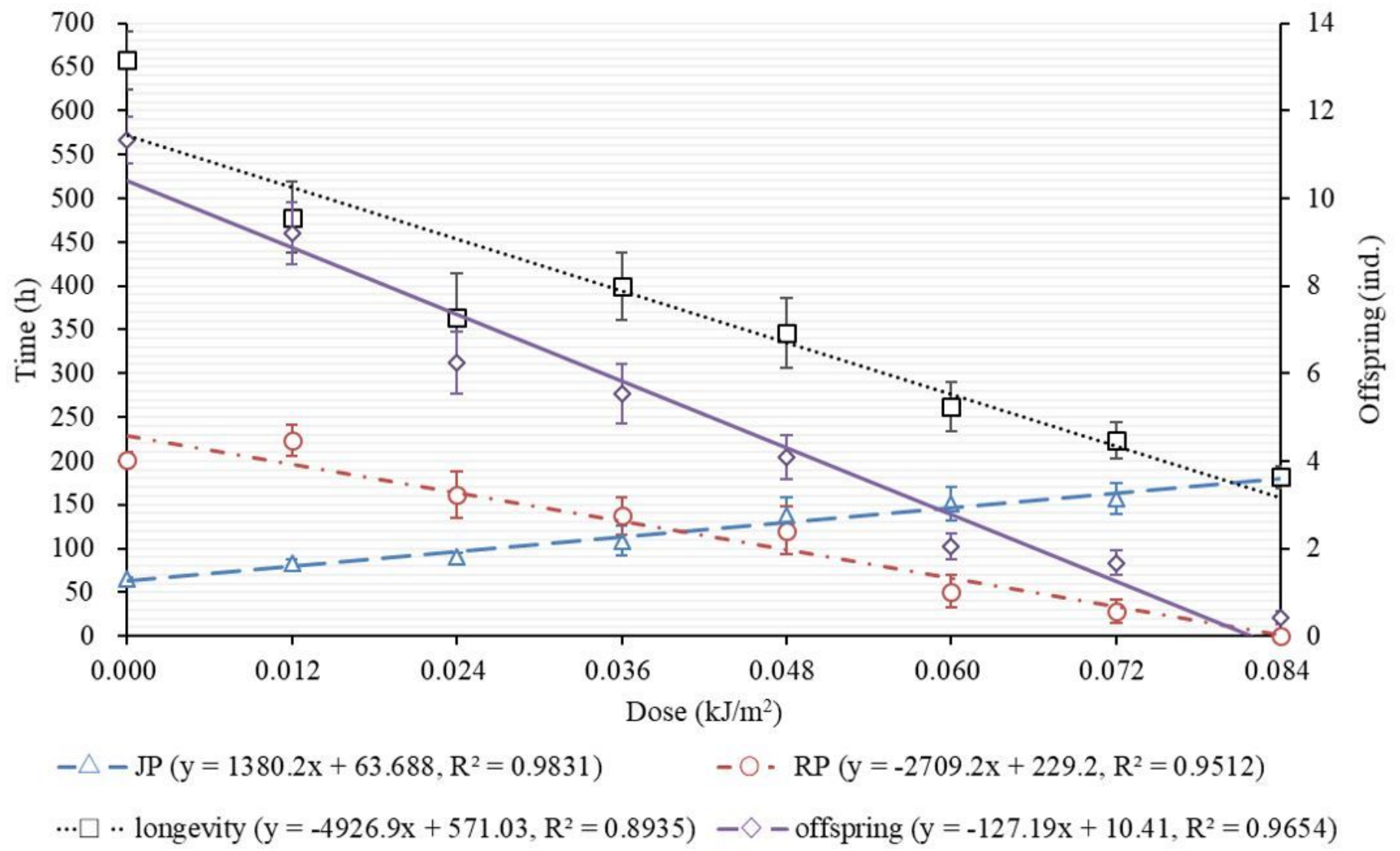

\section{Figure 2}

The life history parameters of the $R$. rotatoria under different radiation treatments (Mean \pm SE). (JP, the durations of juvenile period; RP, the durations of reproductive period) 


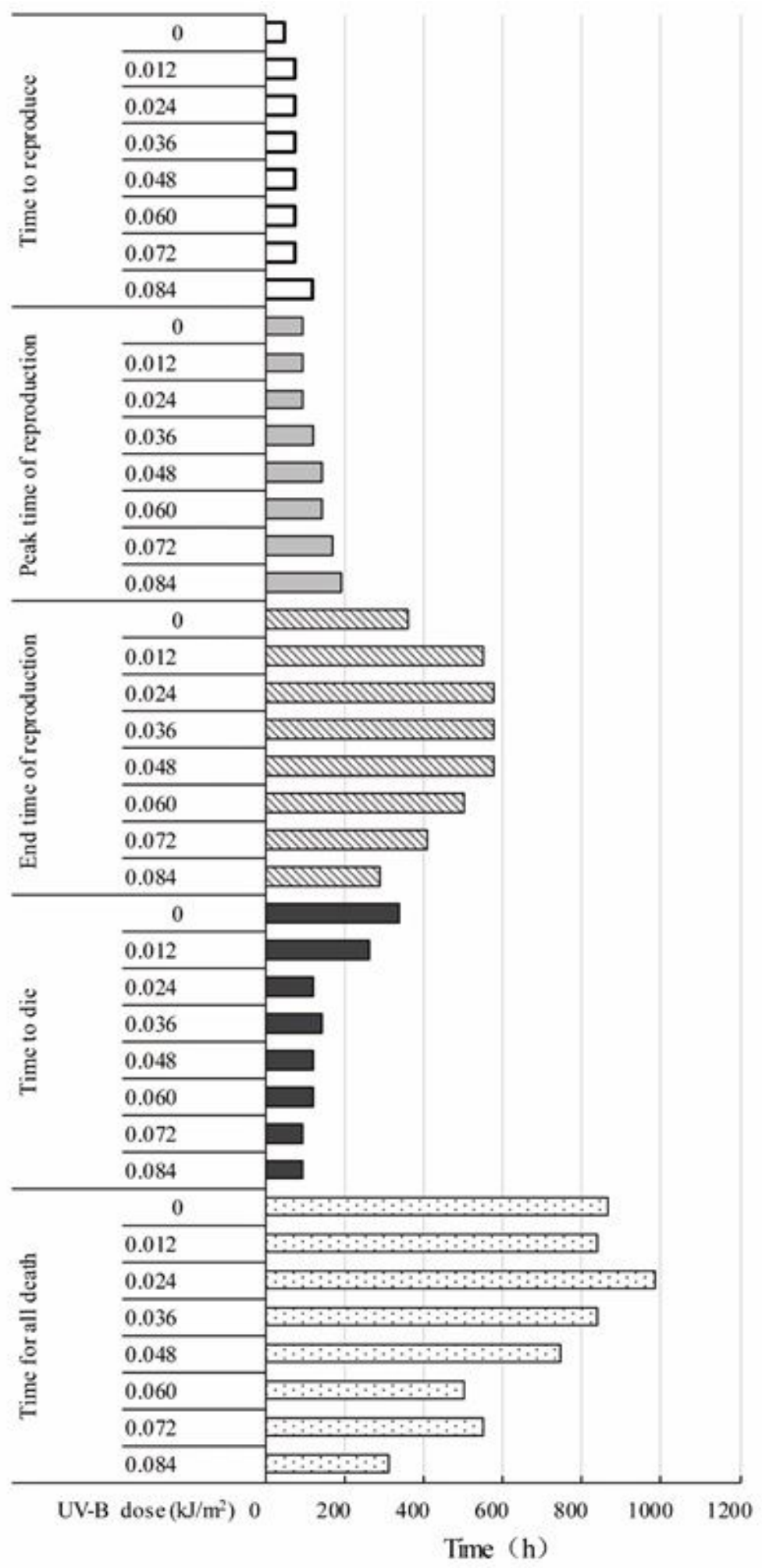

\section{Figure 3}

The timing of age-specific survivorship and reproduction in the R. rotatoria under different radiation doses. 


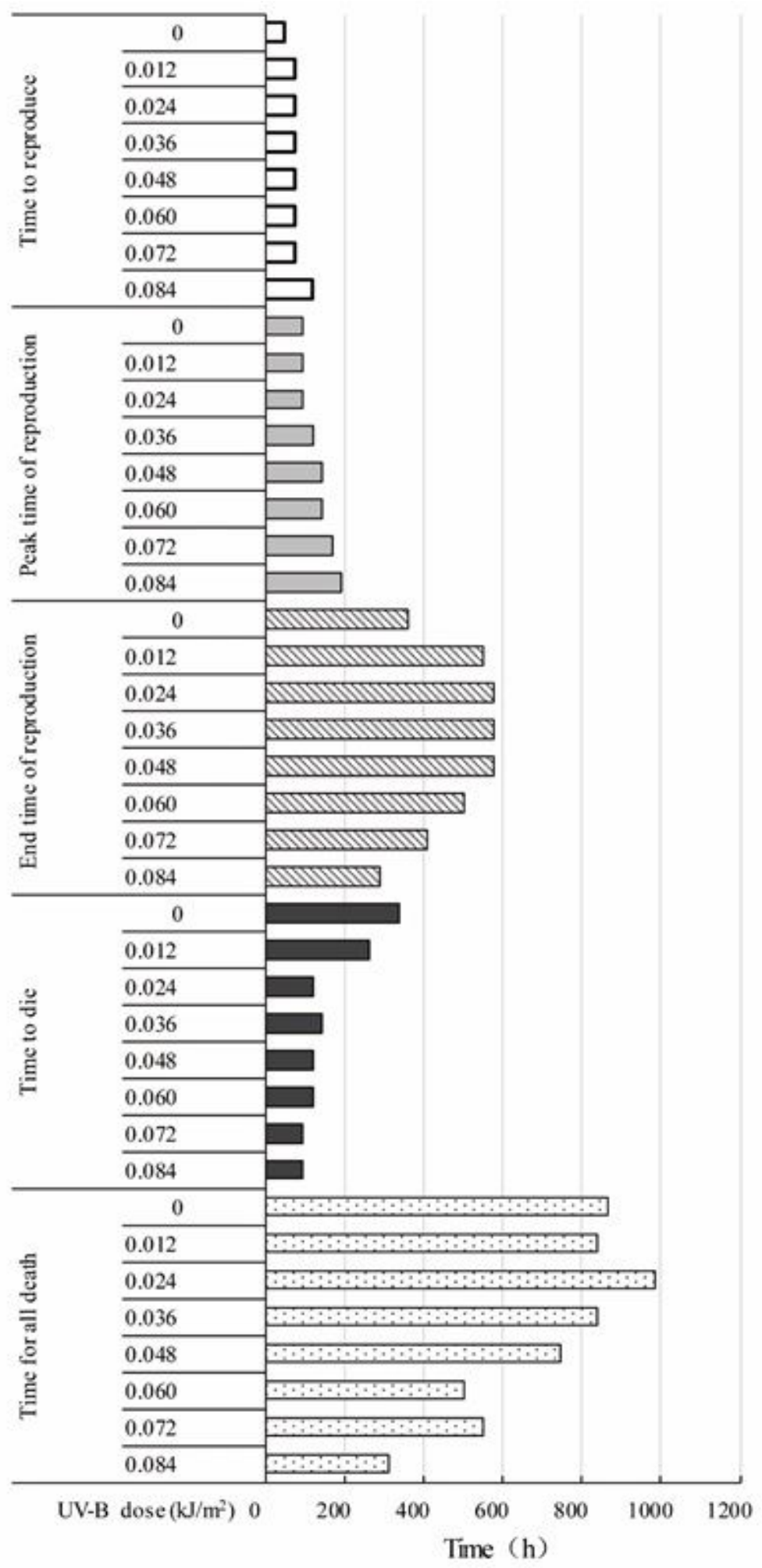

\section{Figure 3}

The timing of age-specific survivorship and reproduction in the R. rotatoria under different radiation doses. 


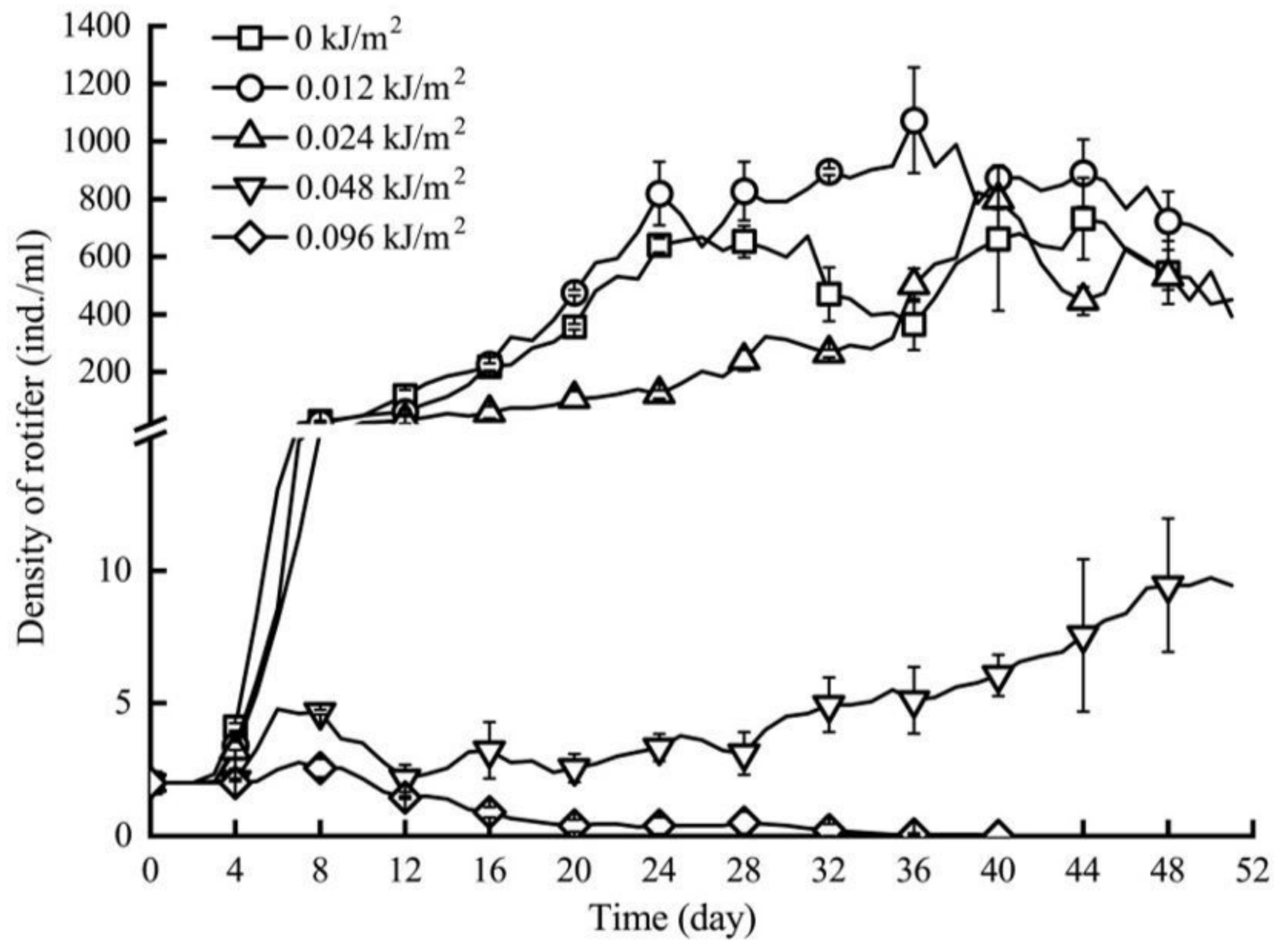

Figure 4

Effects of UV-B radiation treatment on the population density of R. rotatoria. 


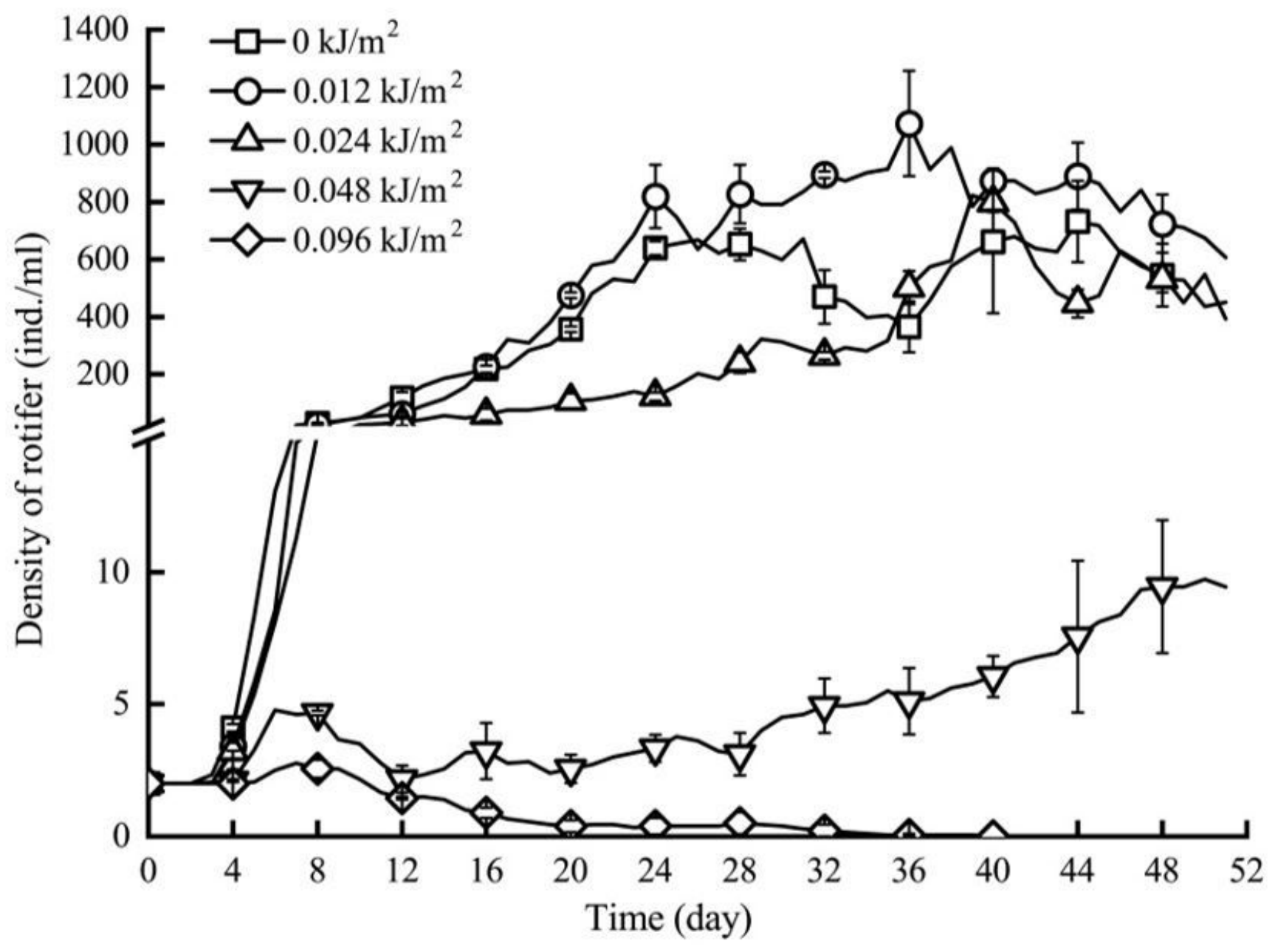

Figure 4

Effects of UV-B radiation treatment on the population density of R. rotatoria.
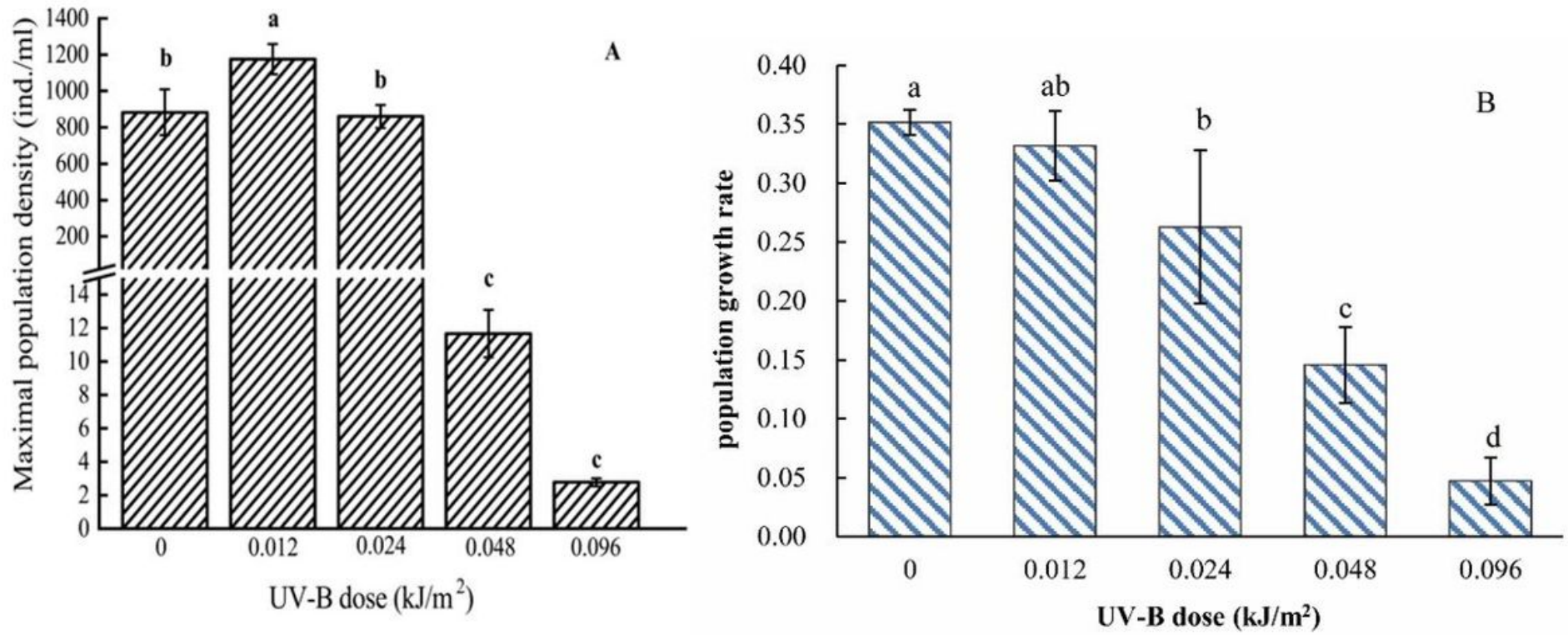


\section{Figure 5}

The maximum population density (A) and population growth rate (B) of R. rotatoria under the five UV-B radiation treatments. Note: SNK-q multiple comparison; Letters ( $a, b, c$ and d) represent the significance of differences among treatment levels, respectively; Treatments with the same letter are not significantly different, whereas treatments with different letters are significantly different.
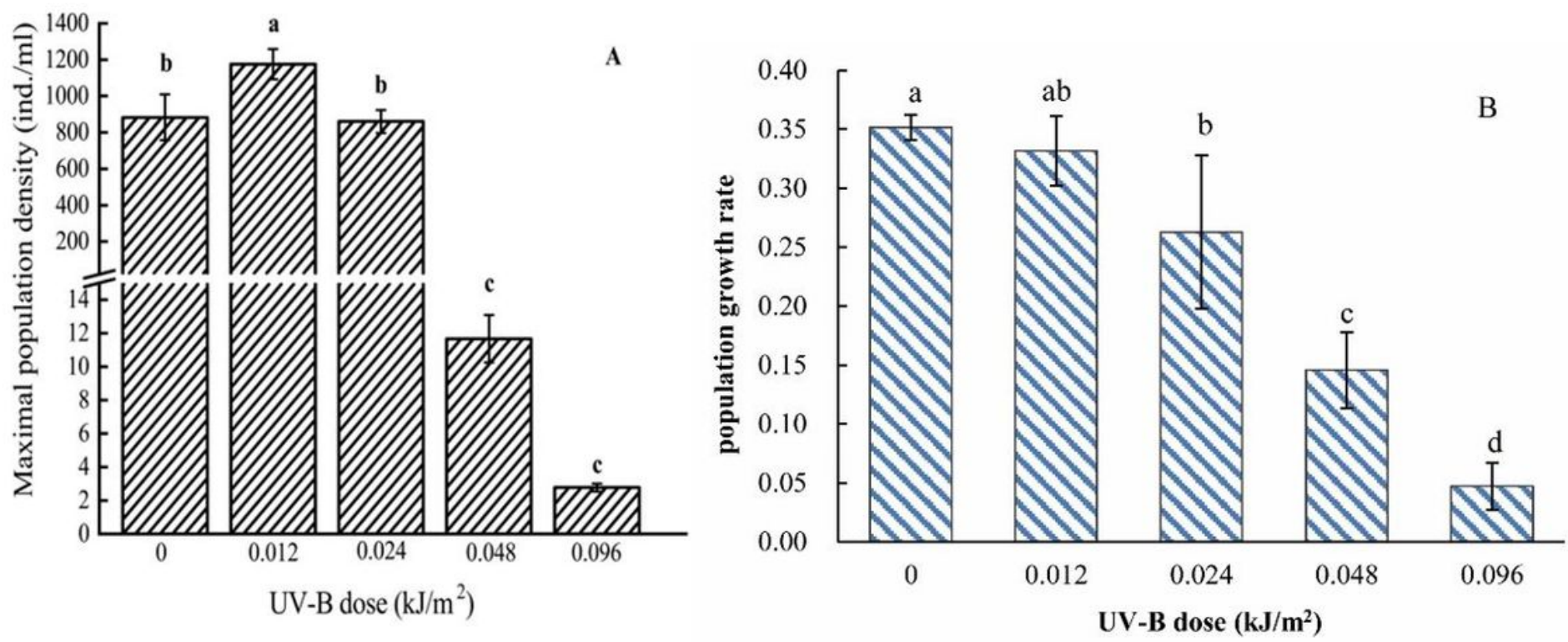

Figure 5

The maximum population density (A) and population growth rate (B) of R. rotatoria under the five UV-B radiation treatments. Note: SNK-q multiple comparison; Letters ( $a, b, c$ and d) represent the significance of differences among treatment levels, respectively; Treatments with the same letter are not significantly different, whereas treatments with different letters are significantly different.
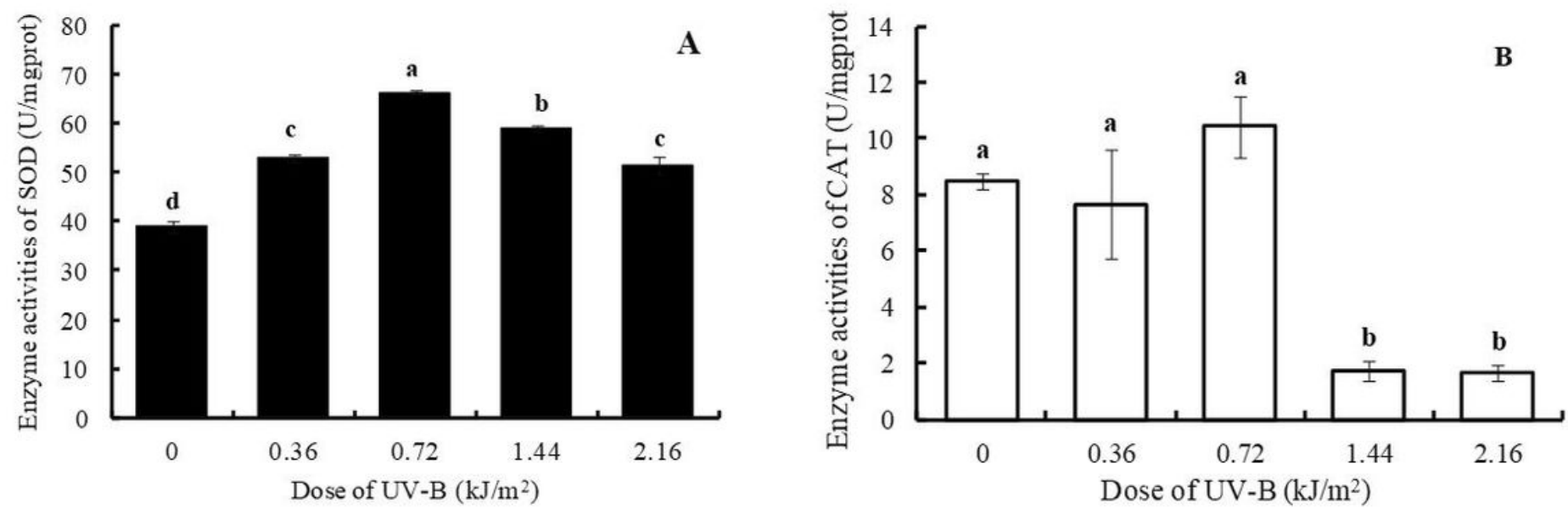

Figure 6 
The enzyme activities of SOD (A) and CAT (B) after the UV-B radiation treatment. Note: SNK-q multiple comparison; Letters ( $a, b, c$ and d) represent the significance of differences among treatment levels, respectively; Treatments with the same letter are not significantly different, whereas treatments with different letters are significantly different.
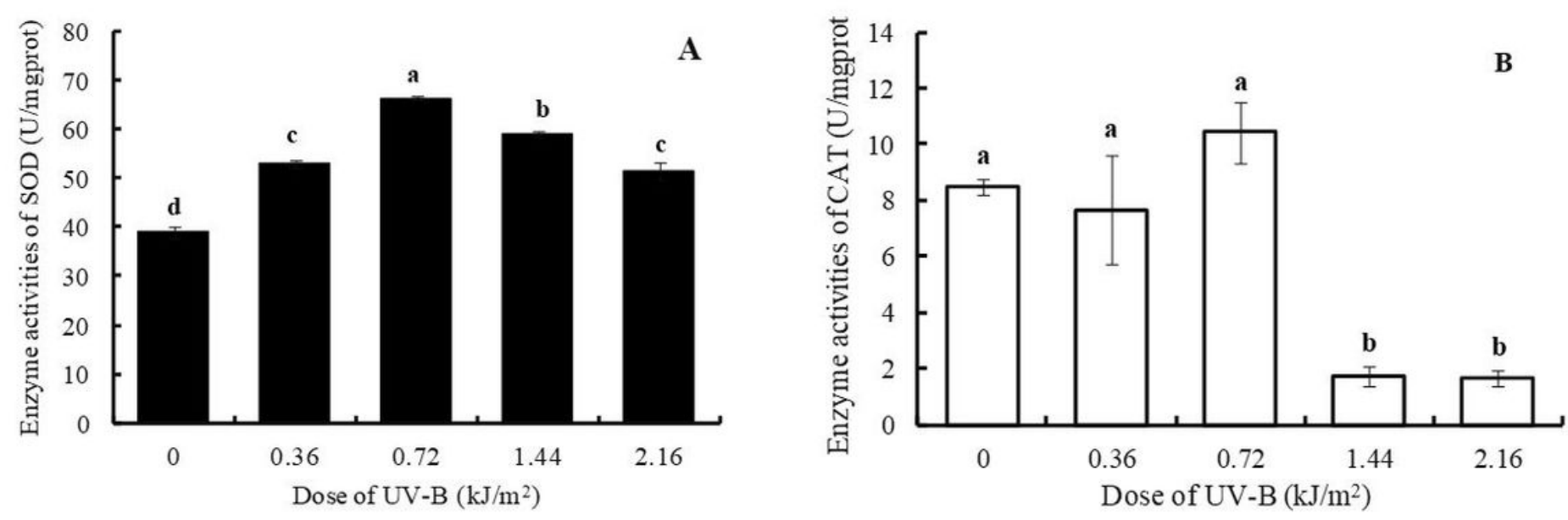

Figure 6

The enzyme activities of SOD (A) and CAT (B) after the UV-B radiation treatment. Note: SNK-q multiple comparison; Letters ( $a, b, c$ and d) represent the significance of differences among treatment levels, respectively; Treatments with the same letter are not significantly different, whereas treatments with different letters are significantly different. 


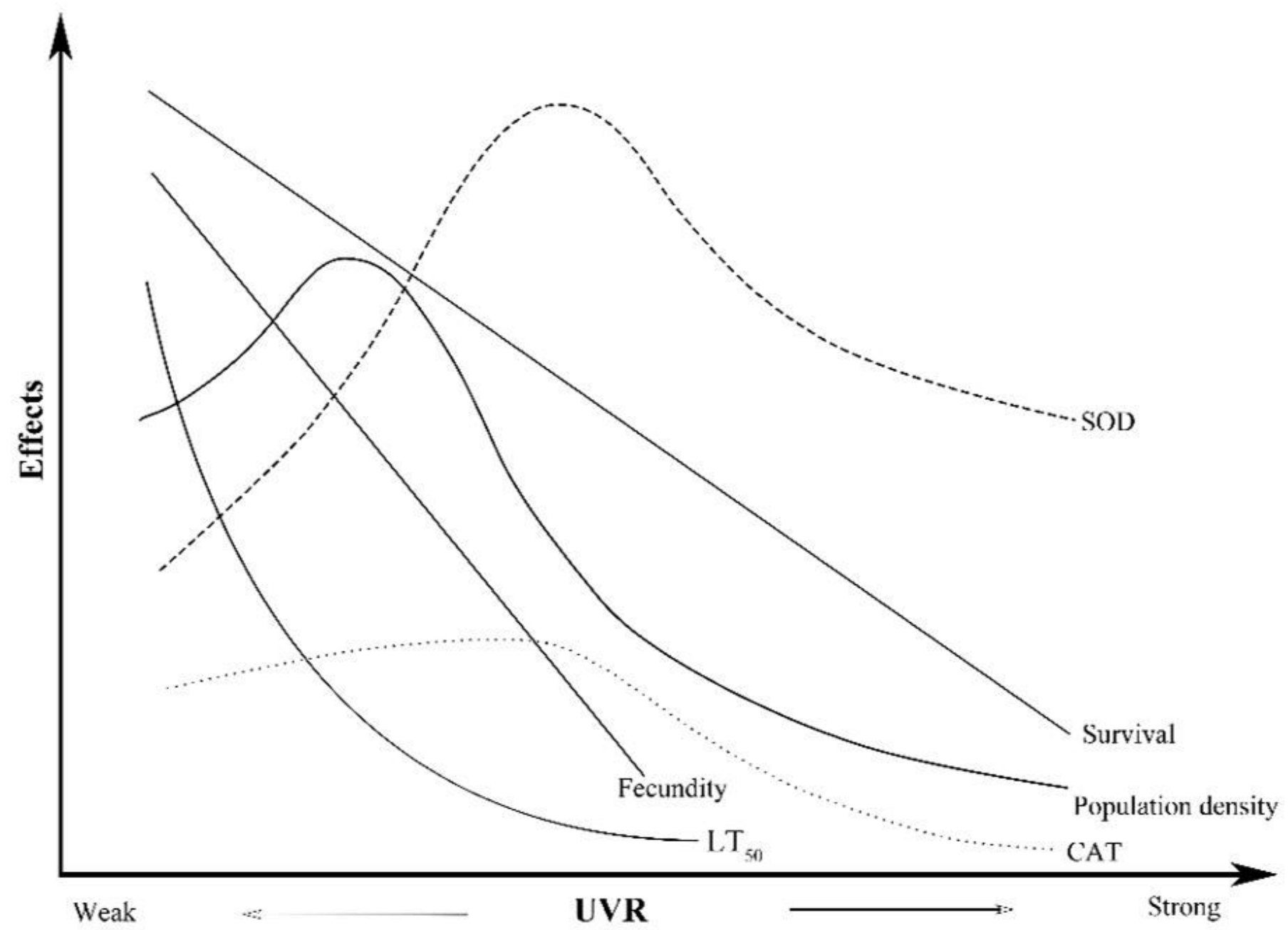

Figure 7

The presumptive model about the changes of testing parameters in R. rotatoria under UV-B radiation. 


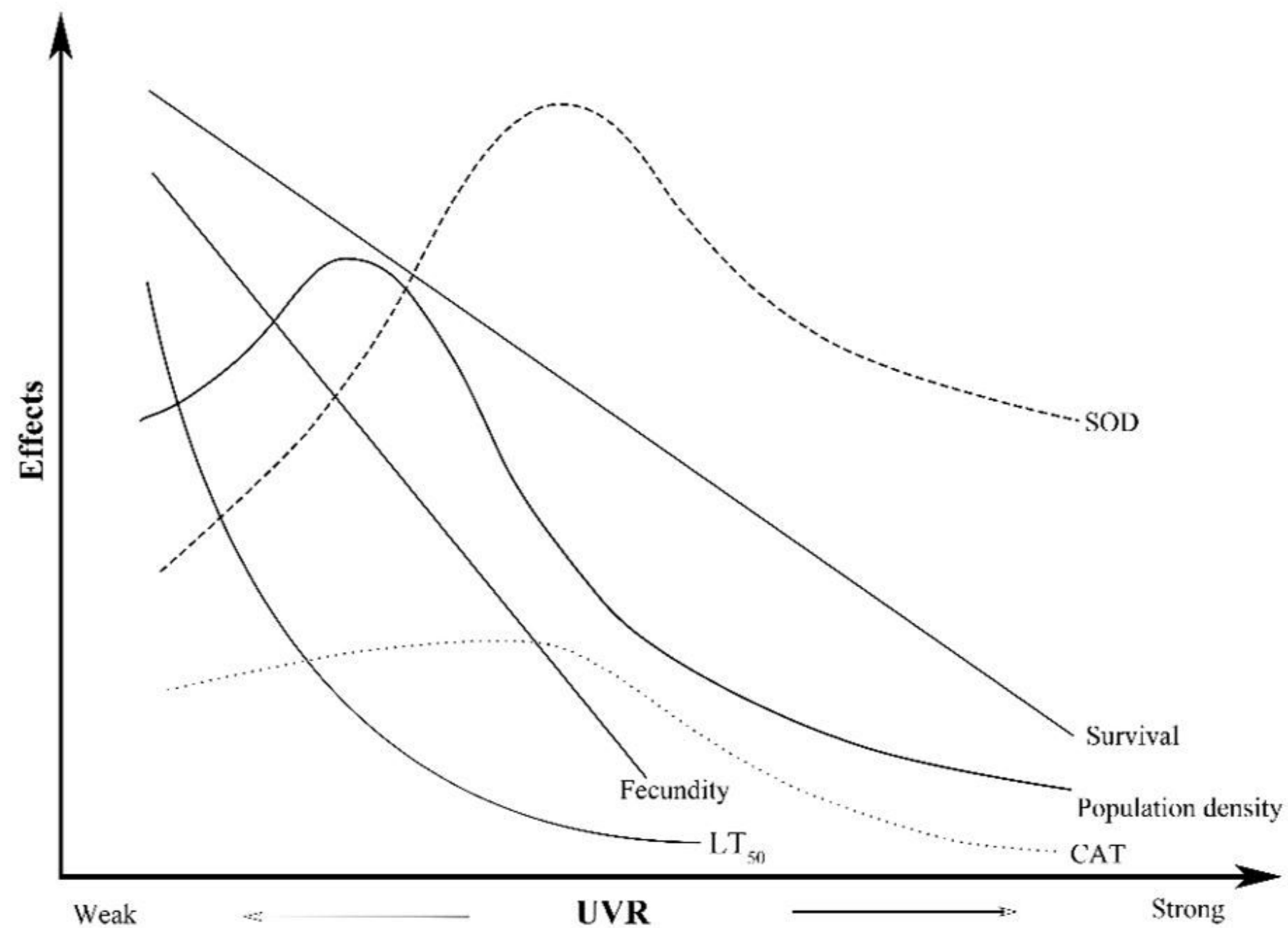

Figure 7

The presumptive model about the changes of testing parameters in R. rotatoria under UV-B radiation.

\section{Supplementary Files}

This is a list of supplementary files associated with this preprint. Click to download.

- GB.jpg

- GB.jpg

- Additionalfile1Tab.S1.docx

- Additionalfile1Tab.S1.docx

- Additionalfile2Fig.S1.eps

- Additionalfile2Fig.S1.eps 